\title{
Nitrogen and Potassium Fertilizers Increase Cherry Tomato Height and Yield
}

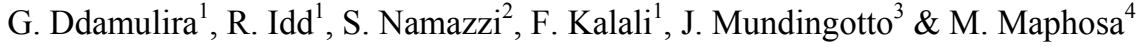 \\ ${ }^{1}$ National Crops Resource Research Institute, Kampala, Uganda \\ ${ }^{2}$ World Vegetable Centre (Worldveg), Kampala, Uganda \\ ${ }^{3}$ Kyambogo University, Kampala, Uganda \\ ${ }^{4}$ Lupane State University, Bulawayo, Zimbabwe \\ Correspondence: G. Ddamulira, Horticulture and Oil Palm Programme, National Crops Resources Research \\ Institute, Kampala, Uganda. Tel: 256-774-229-749. E-mail: ddamuliragab@yahoo.co.uk
}

\author{
Received: October 16, $2018 \quad$ Accepted: June 1, $2019 \quad$ Online Published: August 15, 2019 \\ doi:10.5539/jas.v11n13p48 URL: https://doi.org/10.5539/jas.v11n13p48
}

\begin{abstract}
Less or no fertilizer use compromises growth and yield of cherry tomato (Solanum lycopersicum var. Cerasiforme) in Uganda. A study was conducted to determine the effect of nitrogen (N) and potassium (K) fertilizer rates on cherry tomato growth and yield. The experiment was conducted in a field during 2016B and 2017A seasons at Namulonge. The treatments included; $(100,60,100)$ and $(200,60,200) \mathrm{kg} \mathrm{ha}^{-1}$ of N, P, K and the control with no fertilizer application, these were laid out in a split plot design with three replications. Results revealed that tomato plants significantly $(\mathrm{P}<0.05)$ responded to nitrogen and potassium fertilizer application by increasing their height and yield. The highest tomato height and yield were obtained from plots applied with 100 , $60,100 \mathrm{~kg} \mathrm{ha}^{-1}$ of $\mathrm{N}, \mathrm{P}$ and $\mathrm{K}$. This rate was considered as the optimal application rate because plants applied with fertilizer above this rate were observed to have low height and yield. On the other hand, plants applied with nitrogen and potassium fertilizers below 100, 60, $100 \mathrm{~kg} \mathrm{ha}^{-1}$, flowered and matured earlier than those in the control plots. The study showed that $\mathrm{N}$ and $\mathrm{K}$ fertilizer influenced plant height, flowering, maturity period and yield of cherry tomato. Based on these findings, use of $100,60,100 \mathrm{~kg} \mathrm{ha}^{-1}$ of $\mathrm{N}, \mathrm{P}$ and $\mathrm{K}$ is recommended for improving cherry tomato production in central Uganda, where the study was conducted, and any fertilizer rate above $100,60,100 \mathrm{~kg} \mathrm{ha}^{-1}$ in the same area may be un-economical to use in cherry tomato growing.
\end{abstract}

Keywords: fertilizer, inorganic, Solanum lycopersium var. Cerasiforme

\section{Introduction}

Tomato (Solanum lycopersicum L.) is considered among the most important vegetable crop consumed globally (Arujo et al., 2016). Cherry tomato (Solanum lycopersicum var. Cerasiforme) is small type, attractive with tasty fruits compared to fresh market tomato. It can be consumed in several ways: fresh in salads and sandwiches, cooked, or processed in ketchup, sauces, juices or dried powder. Cherry tomatoes play a major role in human nutrition of providing essential amino acids, vitamins, and minerals. The crop is rich in vitamin $\mathrm{C}$ and contains lycopene, a very vital antioxidant which prevents cancers (Beckles, 2012). In addition, the crop is also a good source of income for smallholder farmers especially women who sell the fresh fruits in markets within their locality (YAP, 2016). Because of the economic and nutritional value of cherry tomato, increasing its production and productivity with good yield and high quality is a major goal for farmers whose aim is to market and sell beyond local markets like supermarkets, regional and international markets. Cherry tomatoes have a premium price on the market compared to the fresh market tomato.

Earlier studies by Ortas (2013) showed that high fruit quality in tomato is influenced by high levels of potassium (K). But, currently it is a common practice among farmers to use less or no K fertilizers (El-Bassiony, 2006), yet for most vegetable crops, their yield response to nitrogen $(\mathrm{N})$ and $\mathrm{K}$ is critical for proper plant growth and fruit quality. Cherry tomato farmers in Uganda are not an exception, they often use less or no fertilizer and as a consequence, the yield and fruit quality are affected. Tomato generally takes up large amounts of nutrients from the soil (Ortas, 2013). Therefore, application of $\mathrm{N}$ and $\mathrm{K}$ fertilizer is important for better nutrient management by farmers to guarantee quality fruit production. 
Studies have shown that a linear relationship exists between relative growth rate and plant $\mathrm{N}$ concentration. Nitrogen is among the essential nutrient for plant growth including tomato. On the other hand, $\mathrm{K}$ is equally important in horticultural crops for better fruit quality, yet the two nutrients are seldom applied in vegetable crops (Savvas et al., 2008). Gupta and Sengar (2000) reported that K fertilizer increases plant growth, yield, quality and the chemical composition of tomato. It is also important in plant development because it plays a major role in physiological and biochemical processes such as enzyme activation; metabolism of carbohydrates and protein compounds (Zhen et al., 1996). Potassium is the most prominent inorganic chemical influencing plant physiology with a significant role to play in the plant energy status for storage of assimilates and tissue water relation (Marschner, 1995). Furthermore, $\mathrm{K}$ improves fruit size and stimulates root growth hence contributing enormously to fruit quality (El-Bassiony, 2006). Furthermore, research by Ortas (2013) indicated that increase in $\mathrm{N}$ and $\mathrm{K}$ uptake and constant level of $\mathrm{P}$ contributes to increased yield of fresh market tomato. These findings attest to the importance of $\mathrm{N}$ and $\mathrm{K}$ application in increasing tomato productivity.

In the last decade, the demand and consumption of cherry tomato have increased. This has forced farmers to start growing cherry tomato commercially in open fields with varying levels of fertilizer application. However, it is still not yet known exactly how much $\mathrm{N}$ and $\mathrm{K}$ must be applied by farmers under Ugandan soil conditions to obtain optimal yield for cherry tomatoes. Cherry tomato growers use a composite fertilizer NPK without knowing the exact levels of $\mathrm{N}$ and $\mathrm{K}$ required to leverage their yield. Hence it is important to determine the $\mathrm{N}$ and $\mathrm{K}$ fertilizer requirements for optimal production of cherry tomato in Uganda. Ortas, (2013) tested different fertilizers rates containing 0,200 and $300 \mathrm{mg} \mathrm{kg}^{-1}$ of $\mathrm{N}$ and $\mathrm{P}$ on fresh market tomato grown under field conditions and found that the two fertilizer levels influence growth, yield and fruit quality of fresh market tomato. $\mathrm{He}$ also concluded that $\mathrm{N}$ concentration of the nutrient solution should not be more than $200 \mathrm{mg} \mathrm{kg}^{-1}$. However, it is necessary to quantify how much $\mathrm{N}$ and $\mathrm{K}$ fertilizers are required for optimum yield production in cherry tomato, since nutrient requirement differ depending on tomato type and soil type. For sustainable use of fertilizer, the right amount needs to be known to save farmers from wastage and excess use which is detrimental to the environment. Hence the objective of the study was to determine the effect of $\mathrm{N}$ and $\mathrm{K}$ fertilizer rates on cherry tomato vegetative growth and yield under field conditions.

\section{Materials and Methods}

\subsection{Study Area}

The experiment was conducted at National Crops Resources Research Institute (NaCRRI), Namulonge in Wakiso district, $19 \mathrm{~km}$ north of Kampala. Namulonge lies at an altitude of 1150 meters above sea level with a bimodal rainfall pattern punctuated with red sandy clay loam soils of $\mathrm{pH}$ 4.9-5.0. The rainfall and temperatures for Namulonge during the experimental period are illustrated in table 1

Table1. Mean Monthy rainfall and temperature at Namulonge during 2016B and 2017A seasons

\begin{tabular}{|c|c|c|c|c|c|c|c|}
\hline \multicolumn{4}{|c|}{ Season 2016B } & \multicolumn{4}{|c|}{ Season 2017A } \\
\hline \multirow{2}{*}{ Months } & \multirow{2}{*}{ Rainfall (mm) } & \multicolumn{2}{|c|}{ Temperature $\left({ }^{\circ} \mathrm{C}\right)$} & \multirow{2}{*}{ Months } & \multirow{2}{*}{ Rainfall (mm) } & \multicolumn{2}{|c|}{ Temperature $\left({ }^{\circ} \mathrm{C}\right)$} \\
\hline & & Minimum & Maximum & & & Minimum & Maximum \\
\hline September & 90.0 & 17.9 & 29.3 & March & 93.3 & 16.3 & 29.6 \\
\hline October & 29.4 & 17.6 & 30.4 & April & 160.3 & 17.4 & 28.9 \\
\hline November & 115.1 & 17.5 & 29.2 & May & 64.3 & 17.2 & 27.7 \\
\hline December & 43.2 & 17.7 & 31.0 & June & 2.9 & 16.8 & 28.9 \\
\hline
\end{tabular}

\subsection{Plant Materials}

The seven-cherry tomato accessions evaluated were obtained from a core tomato collection held by Kyambogo University Kampala. The accessions were collected in 2015 from 15 major tomato growing districts in Uganda. The seven cherry tomato accessions used in this study were selected based on results accruing from a characterization process which identified them as high yielding with tolerance to tomato insect pests and diseases in Uganda.

\subsection{Seedling Production}

Tomato seedlings were produced in a nursery bed by initially sowing seeds of the seven accessions in a mixture of forest soil, sand and manure in a ratio of 3:1:1. The seedlings emerged 7 days after planting and regular watering was done accompanied with spraying of cypermethrin at a rate of $2 \mathrm{ml} \mathrm{L}^{-1}$ to control cutworms and 
other insect pests that are known to damage tomato seedlings while in the nursery (Abu-EL Samen et al., 2015). The seedlings were maintained in the nursery for 21 days before being transplanted into the main field.

\subsection{Soil Analyse}

Prior to experimental setup, the soil status of the experimental site was ascertained by picking 10 soil samples at a depth of $0-20 \mathrm{~cm}$. The samples were composited into five samples and taken to the laboratory for analysis. The composite soil samples were air-dried, ground and passed through a 2-mm sieve and prepared for routine analysis of texture, $\mathrm{pH}$, organic matter $(\mathrm{OM})$, total nitrogen $(\mathrm{N})$, exchangeable calcium $(\mathrm{Ca})$, magnesium $(\mathrm{Mg})$, potassium $(\mathrm{K})$, and available phosphorus $(\mathrm{P})$ in triplicates. The texture was determined by hydrometer method (Bouyoucos, 1927) and soil $\mathrm{pH}$ was measured using glass electrode method with a soil-to-water ratio of 1:2.5. The soil organic matter was determined according to Walkley and Black method 1934. Soil total N was determined by micro-Kjeldahl method (Bremner \& Mulvaney, 1982). Available soil P was extracted using Olsen's method (Olsen \& Sommers, 1982). Exchangeable $\mathrm{Ca}$ and $\mathrm{Mg}$ were determined by an atomic spectrophotometer (Okalebo, 2002) and K by a flame photometer (Thomas, 1982).

Table 2. Selected, physical-chemical and biological properties of soils at Namulonge

\begin{tabular}{lll}
\hline \multirow{2}{*}{ Properties } & Units & Depth $(\mathrm{cm})$ \\
\cline { 3 - 3 } & & $0-20$ \\
\hline Sand & $\%$ & 47.0 \\
Clay & $\%$ & 42.3 \\
Silt & $\%$ & 10.8 \\
Organic matter & $\%$ & 2.3 \\
Calcium & ppm & 1502.2 \\
pH & & 5.6 \\
Mg & ppm & 359.6 \\
$\mathrm{~N}($ Total $)$ & $\%$ & 0.17 \\
$\mathrm{P}$ & $\mathrm{ppm}$ & 5.8 \\
$\mathrm{~K}$ & $\mathrm{ppm}$ & 27.7 \\
\hline
\end{tabular}

\subsection{Field Experiment}

The experiment was laid out in a split plot design with three replicates. The seedlings were planted in plots of 4 $\mathrm{m}$ long and $4 \mathrm{~m}$ wide at a spacing of $60 \mathrm{~cm}$ between rows and plants. The seven tomato accessions constituted the main plots and fertilizer levels as the split plots. Treatments of NPK were applied at two rates of 100,60, 100 $\left(\mathrm{N}_{100} \mathrm{P}_{60} \mathrm{~K}_{100}\right), 200,60,200\left(\mathrm{~N}_{200} \mathrm{P}_{60} \mathrm{~K}_{200}\right) \mathrm{kg} \mathrm{ha}^{-1}$ of $\mathrm{N}$ and $\mathrm{K}_{2} \mathrm{O}$, and the control where no fertilizer was applied. Nitrogen used as ammonium nitrate $\left(\mathrm{NH}_{4} \mathrm{NO}_{3}\right)$ and potassium as potassium sulphate $\left(\mathrm{K}_{2} \mathrm{SO}_{4}\right)$ obtained from urea and murate of potash. Prior to transplanting each plot was applied with a uniform rate of $60 \mathrm{~kg} \mathrm{P}_{2} \mathrm{O}_{5} \mathrm{~kg} \mathrm{ha}^{-1}$ supplied as triple superphosphate (TSP). Nitrogen and potassium fertilizer levels were applied to the soil three times at equal and constant levels (the first portion was applied at transplanting, the second, at two week after transplanting and the third was top-dressed at flowering stage. Three weeding regimes using a hand hoe was done to control weeds. Cypermethrin was applied at a rate of $5 \mathrm{ml} \mathrm{L}^{-1}$ to control insect pests, while Mancozeb a fungicide was applied at a rate of $2.5 \mathrm{~g} \mathrm{~L}^{-1}$ to control fungal infections

\subsection{Plant Analysis}

At flowering stage, twenty completely developed leaves were picked from the central position of branches of the seven tomato accessions for $\mathrm{N}, \mathrm{P}$ and $\mathrm{K}$ analysis. The $\mathrm{N}$ and $\mathrm{K}$ contents of leaves were determined on composite samples which were composited from five plants of the same accessions in each plot per accessions. The samples were oven-dried, ground, and analyzed for nitrogen $(\mathrm{N})$ using the Kjeldahl method (Anderson \& Ingram, 1993) and phosphorus (P) by a spectrophotometer (Olsen \& Sommers, 1982), and potassium (K) with a flame photometer (Thomas, 1982).

\subsection{Data Collection and Analysis}

During vegetative growth data on plant height $(\mathrm{cm})$ was collected, data on days to flowering was collected at the initiation of reproductive growth stage, while data on days to maturity and yield was gathered at fruit physiological maturity. All the data were subjected to analysis of variance (ANOVA) for a completely 
randomized split design using Genstat software version 11 (Payne et al., 2011) and results were expressed as mean values. Significances of treatment means were derived using the least significant difference.

\section{Results}

\subsection{Plant Height}

Statistical analysis showed that plant height varied significantly $(\mathrm{P}<0.05)$ between seasons, tomato accessions and fertilizer rates. Plant height measured during season 2017A was much higher $(30.5 \mathrm{~cm})$ compared to height recorded in season 2016B $(19.8 \mathrm{~cm})$. The analysis also indicated that fertilizer rates significantly $(\mathrm{P}<0.05)$ influenced cherry tomato height. Generally, tomato plants applied with $\mathrm{N}_{100} \mathrm{P}_{60} \mathrm{~K}_{100}$ fertilizer were taller than plants in control plots as well as those applied with $\mathrm{N}_{200} \mathrm{P}_{60} \mathrm{~K}_{200}$ fertilizers.

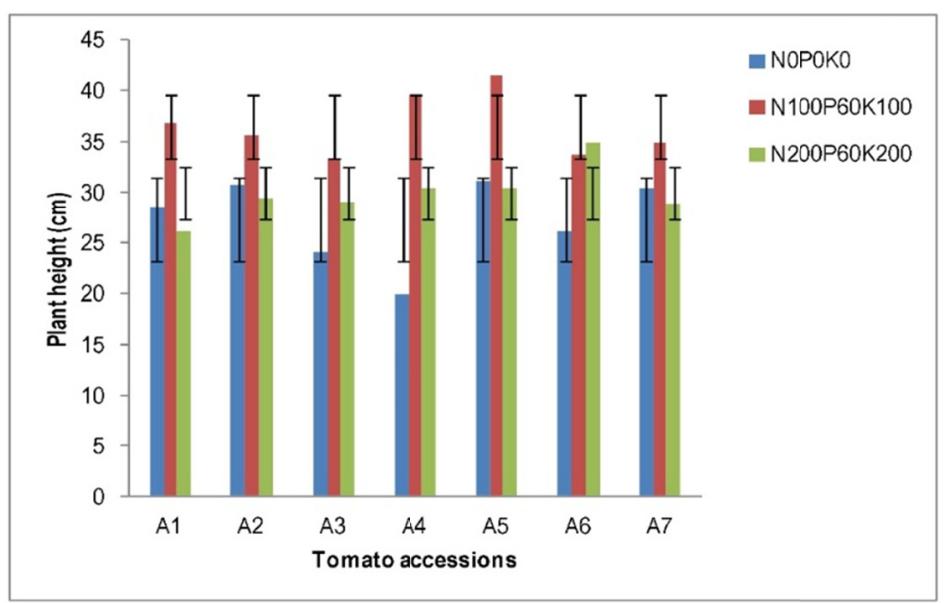

Figure 1. Height of seven cherry tomato accessions in 2016B season; A1-A7 are tomato accessions and $\mathrm{N}_{0} \mathrm{P}_{0} \mathrm{~K}_{0}$, $\mathrm{N}_{100} \mathrm{P}_{60} \mathrm{~K}_{100}$ and $\mathrm{N}_{200} \mathrm{P}_{60} \mathrm{~K}_{200}$ in $\mathrm{kg} \mathrm{ha}^{-1}$ are application rates of $\mathrm{N}, \mathrm{P}$ and $\mathrm{K}$ respectively

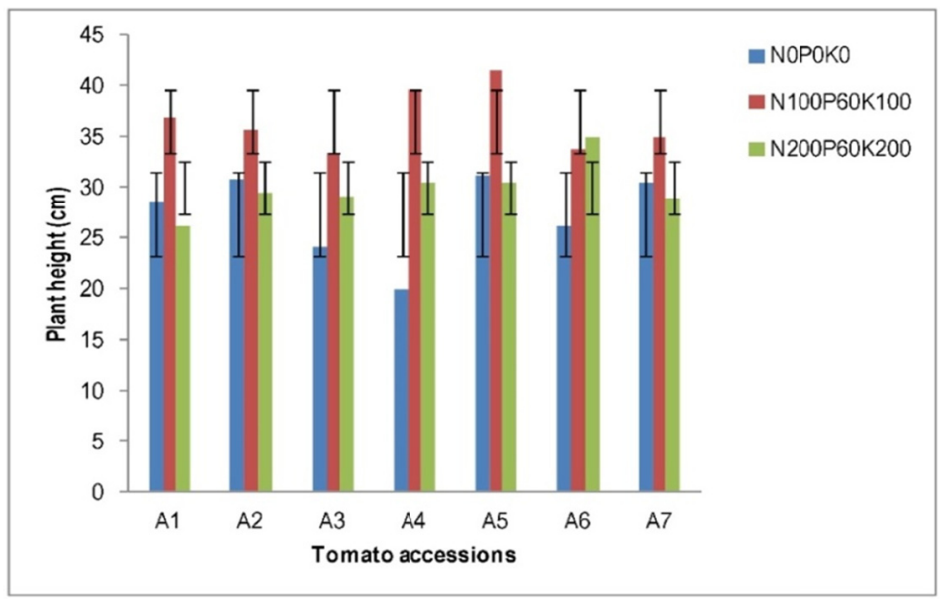

Figure 2. Height of seven cherry tomato accessions in 2017A season; A1-A7 are tomato accessions and $\mathrm{N}_{0} \mathrm{P}_{0} \mathrm{~K}_{0}$, $\mathrm{N}_{100} \mathrm{P}_{60} \mathrm{~K}_{100}$ and $\mathrm{N}_{200} \mathrm{P}_{60} \mathrm{~K}_{200}$ in $\mathrm{kg} \mathrm{ha}^{-1}$ are application rates of $\mathrm{N}, \mathrm{P}$ and $\mathrm{K}$ respectively

There was significant $(\mathrm{P}<0.05)$ variation in the plant height as influenced by differences in accessions and seasons. Due to significant interaction between season and accessions a combined analysis of season data was not done, instead each season data was treated differently during analysis. In season 2016B the highest and lowest height were recorded in tomato accession A1 and A2, respectively (Figure 1). On the other hand, the highest and lowest plant height in season 2017A was observed in accessions A5 and A3. In general, application of $\mathrm{N}_{100} \mathrm{P}_{60} \mathrm{~K}_{100}$ fertilizer induced plants to exhibit long stems as compared to the control for all accessions (Figure 2). 


\subsection{Tomato Nutrient Content}

A significant $(\mathrm{P}<0.05)$ difference in $\mathrm{N}, \mathrm{P}$ and $\mathrm{K}$ content in plant tissue as influenced by the application of $\mathrm{N}$ and $\mathrm{K}$ fertilizer was observed (Table 2). Increasing $\mathrm{N}$ and $\mathrm{K}$ application increased $\mathrm{N}$ and $\mathrm{K}$ in tomato tissues up to the optimal level, beyond which decreasing $\mathrm{N}$ and $\mathrm{K}$ levels in plant tissues were recorded. However, no significant variation in $\mathrm{N}$ and $\mathrm{K}$ levels in plant tissues were observed between the two seasons for which the cherry tomatoes were evaluated. Nonetheless, $\mathrm{N}$ and $\mathrm{K}$ content in plant tissue varied significantly $(\mathrm{P}<0.05)$ among different accessions. The highest $\mathrm{N}$ was reported in accession $\mathrm{A} 3$ while the least $\mathrm{N}$ content was observed in accession A5. On the other hand, accessions A1 and A6 contained the highest and the lowest $\mathrm{K}$ content in their tissues, respectively (Table 2).

Table 2. Nitrogen and Potassium content in different tomato accession leaf tissues as influenced by the application of different concentration levels of $\mathrm{N}$ and $\mathrm{K}$ fertilizers at Namulonge

\begin{tabular}{lllllllll}
\hline Treatments & A1 & A2 & A3 & A4 & A5 & A6 & A7 & Mean \\
\hline Control & -2.507 & 2.896 & 3.305 & 2.795 & 2.787 & 2.492 & 2.706 & 2.784 \\
$\mathrm{~N}_{100} \mathrm{P}_{60} \mathrm{~K}_{100}$ & 3.742 & 2.492 & 4.804 & 2.701 & 1.789 & 2.687 & 3.013 & 3.033 \\
$\mathrm{~N}_{200} \mathrm{P}_{60} \mathrm{~K}_{200}$ & 4.544 & 2.116 & 2.784 & 2.496 & 2.493 & 2.591 & 2.592 & 2.779 \\
$\mathrm{Mean}$ & 2.784 & 2.501 & 3.631 & 2.664 & 2.356 & 2.590 & 2.770 & \\
& -3.687 & 3.186 & 3.011 & 2.916 & 3.002 & 2.916 & 3.787 & 3.215 \\
Control & 3.897 & 3.554 & 4.410 & 2.947 & 2.602 & 2.719 & 4.198 & 3.475 \\
$\mathrm{~N}_{100} \mathrm{P}_{60} \mathrm{~K}_{100}$ & 4.194 & 2.702 & 1.850 & 2.804 & 2.886 & 2.402 & 2.507 & 2.764 \\
$\mathrm{~N}_{200} \mathrm{P}_{60} \mathrm{~K}_{200}$ & 3.926 & 3.147 & 3.090 & 2.889 & 2.830 & 2.679 & 3.498 & \\
Mean & - & & & & &
\end{tabular}

Note. ${ }^{1} \mathrm{~A} 1-\mathrm{A} 7$; cherry tomato accessions.

\subsection{Days to Flowering}

In understanding the growth of cherry tomato, days to flowering is an important parameter to consider as it marks a transition from vegetative growth into reproductive stage. In this study fertilizer rates significantly $(\mathrm{P}<$ 0.05 ) influenced days to flowering in a cherry tomato. Plants applied with $\mathrm{N}_{100} \mathrm{P}_{60} \mathrm{~K}_{100}$ fertilizers flowered earlier (49 days) compared to tomato plants in control plots (53 days). On the contrary, days to flowering did not vary among different tomato accessions and no significant interaction was observed between the interactive effect of treatments and accessions.

\subsection{Days to Maturity}

In this study, significant $(\mathrm{P}<0.05)$ variation in days to maturity was observed among fertilizer rates and accessions (Table 3). Accessions applied with $\mathrm{N}_{100} \mathrm{P}_{60} \mathrm{~K}_{100}$ fertilizers matured earliest (80 days) while those in control plots took the longest (87 days) time to mature. On the contrarily, days to maturity of cherry tomato accessions applied with $\mathrm{N}_{200} \mathrm{P}_{60} \mathrm{~K}_{200}$ fertilizers were not significantly different from those in control plots. In terms of accessions, A5 matured earliest and accession A7 took the longest time to mature (Table 3). However, seasons did not have a significant influence on maturity of tomato accessions.

Table 3. Days to maturity of seven cherry tomato accessions as influenced by the different rates of $\mathrm{N}$ and $\mathrm{K}$ fertilizer under field condition at Namulonge

\begin{tabular}{|c|c|c|c|c|c|c|c|}
\hline Treatments & A1 & A2 & $\mathbf{A 3}$ & A4 & A5 & A6 & A7 \\
\hline & ------ & 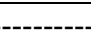 & 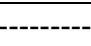 & -- Days & -------- & -------. & - \\
\hline Control & $88.7 \mathrm{a}$ & $81.7 \mathrm{a}$ & $88.7 \mathrm{a}$ & $93.3 \mathrm{a}$ & $73.7 \mathrm{a}$ & $91.0 \mathrm{a}$ & $92.3 \mathrm{a}$ \\
\hline $\mathrm{N}_{100} \mathrm{P}_{60} \mathrm{~K}_{100}$ & $79.0 \mathrm{~b}$ & $79.0 \mathrm{a}$ & $84.0 \mathrm{~b}$ & $81.7 \mathrm{~b}$ & $79.3 b$ & $79.0 \mathrm{~b}$ & $82.7 \mathrm{~b}$ \\
\hline $\mathrm{N}_{200} \mathrm{P}_{60} \mathrm{~K}_{200}$ & $83.7 b$ & $85.3 \mathrm{~b}$ & $85.7 b$ & $86.0 \mathrm{c}$ & $83.7 \mathrm{c}$ & $80.7 b$ & $91.7 \mathrm{a}$ \\
\hline Mean & 83.78 & 82.0 & 86.1 & 87.0 & 78.9 & 83.6 & 88.9 \\
\hline
\end{tabular}

Note. ${ }^{1} \mathrm{~A} 1-\mathrm{A} 7$; cherry tomato accessions; days to maturity means followed by different letters are significantly different and means followed by a similar letter are not significantly different. 


\subsection{Yield}

There was a significant $(\mathrm{P}<0.05)$ variation in tomato yield observed between seasons, treatments and accessions. The highest yield was obtained in 2016B season and the least in 2017A. The average yield obtained in season 2016B was $2509 \mathrm{~kg} \mathrm{ha}^{-1}$ as compared to $1802 \mathrm{~kg} \mathrm{ha}^{-1}$ realized in 2017A. In terms of treatments plants applied with $\mathrm{N}_{100} \mathrm{P}_{60} \mathrm{~K}_{100}$ fertilizers produced the highest yield as compared to the rest of other treatments in both seasons (Table 4). Surprisingly, plants in the control plots yielded more compared to those applied with $\mathrm{N}_{200} \mathrm{P}_{60} \mathrm{~K}_{200}$ fertilizer. Furthermore, cherry tomato accessions provided varying yield depending on seasons. In season 2016B, accessions A4 produced the highest yield $\left(3268 \mathrm{~kg} \mathrm{ha}^{-1}\right)$ while the lowest yield $\left(1310 \mathrm{~kg} \mathrm{ha}^{-1}\right)$ was obtained from accession A6, whereas in season 2017A, the highest yield $\left(2600 \mathrm{~kg} \mathrm{ha}^{-1}\right)$ was obtained from accession A2 and the least yield (1273 $\left.\mathrm{kg} \mathrm{ha}^{-1}\right)$ obtained from accession A5 (Table 4).

Table 4. Mean yield of different cherry tomato accessions under different $\mathrm{N}$ and $\mathrm{K}$ fertilizer levels in seasons 2016B and 2017A at Namulonge

\begin{tabular}{|c|c|c|c|c|c|c|c|c|}
\hline Season & Treatments & A1 & A2 & A3 & A4 & A5 & A6 & A7 \\
\hline & & $---\cdot$ & --- & ----- & $\mathrm{d}(\mathrm{kg} \mathrm{h}$ & --------. & 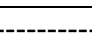 & ---------' \\
\hline \multirow[t]{4}{*}{ 2016B } & Control & $3585 \mathrm{a}$ & $3581 \mathrm{a}$ & $2270 \mathrm{a}$ & $2288 \mathrm{a}$ & $2218 \mathrm{a}$ & $1946 a$ & $4286 a$ \\
\hline & $\mathrm{N}_{100} \mathrm{P}_{60} \mathrm{~K}_{100}$ & $4272 b$ & $2936 b$ & $4353 b$ & $5057 \mathrm{~b}$ & $2830 \mathrm{~b}$ & $1641 \mathrm{a}$ & $2683 b$ \\
\hline & $\mathrm{N}_{200} \mathrm{P}_{60} \mathrm{~K}_{200}$ & $406 c$ & $1457 \mathrm{c}$ & $638 \mathrm{c}$ & $2458 \mathrm{a}$ & $1226 \mathrm{c}$ & $343 b$ & $2216 b$ \\
\hline & Mean & 2755 & 2658 & 2420 & 3268 & 2091 & 1310 & 3062 \\
\hline \multirow[t]{4}{*}{$2017 \mathrm{~A}$} & Control & $2538 \mathrm{~d}$ & $2426 b$ & $1107 \mathrm{~d}$ & $767 \mathrm{c}$ & $1278 \mathrm{c}$ & $1414 \mathrm{a}$ & $2617 b$ \\
\hline & $\mathrm{N}_{100} \mathrm{P}_{60} \mathrm{~K}_{100}$ & $2074 d$ & $2744 b$ & $2294 a$ & $2482 a$ & $1346 \mathrm{c}$ & $2047 \mathrm{c}$ & $1968 \mathrm{c}$ \\
\hline & $\mathrm{N}_{200} \mathrm{P}_{60} \mathrm{~K}_{200}$ & $1416 \mathrm{e}$ & $2631 b$ & $2021 \mathrm{a}$ & $1020 \mathrm{c}$ & $1193 c$ & $979 d$ & $1490 \mathrm{c}$ \\
\hline & Mean & 2009 & 2600 & 1807 & 1423 & 1273 & 1480 & 2025 \\
\hline
\end{tabular}

Note. ${ }^{1} \mathrm{~A} 1-\mathrm{A} 7$; cherry tomato accessions; yield means followed by different letters are significantly different and means followed by a similar letter are not significantly different.

\section{Discussion}

The effect of $\mathrm{N}$ and $\mathrm{K}$ application reduced days to flowering, maturity and increased yield compared to the control. These results demonstrated that use of optimal amounts of $\mathrm{N}$ and $\mathrm{K}$ fertilizer is associated with nutrient uptake which contributes to increased tomato yield. Tomato plant height was affected by seasons, and the increase in plant height during 2017A was possibly due to high rainfall received (Average $80.2 \mathrm{~mm}$ ) compared to season 2016B when low $(69.4 \mathrm{~mm})$ rains were received. A number of studies have reported a reduction in tomato plant height especially under low rainfall (Dry, 1998). The reduction in plant height is a common phenomenon among plants that are sensitive to moisture stress, as a result of low rainfall (Shao, 2014). In tomato, the roots are severely affected by low soil moisture due to reduced root permeability and hydraulic conductivity, which in turn affects uptake and transport of nutrients supplied by fertilizers (Huang, 2000). The reduction in nutrient uptake also affects plant photosynthetic activities, hence retarding plant height. Therefore, it is anticipated that the more rainfall received during season 2017A availed water which facilitated $\mathrm{N}$ and $\mathrm{P}$ uptake to increase photosynthetic activity which led to increased plant height observed.

Application of $\mathrm{N}_{100} \mathrm{P}_{60} \mathrm{~K}_{100}$ affected plant height when compared to the control because nitrogen and potassium fertilizers interact to increase plant growth during the vegetative growth stage. Ortas (2013) reported that nitrogen and potassium fertilization significantly increased tomato height. This study has further revealed that application of $100 \mathrm{~kg} \mathrm{ha}^{-1}$ of $\mathrm{N}$ and $\mathrm{K}$ is the level that can be applied to effectively increase tomato height. Beyond this level application of $\mathrm{N}$ and $\mathrm{P}$ in large amounts negatively affects tomato height as indicated by the study results; when $200 \mathrm{~kg} \mathrm{ha}^{-1}$ of $\mathrm{N}$ and $\mathrm{K}$ at constant $\mathrm{P}$ was applied a significant yield, reduction in height was observed. Similarly, significant variation in plant height observed among accessions was due to the fact that tomato cultivars' response to nutrient utilization depends on their genetic make-up. This was further supported by earlier findings by Sinnaduiai (1992) who reported that plant height varies according to cultivar characteristics or genetic constitution. On the other hand, the significant interaction between seasons and accessions indicated that the two factors interact positively to influence tomato height.

In terms of duration to flowering and maturity, earliest flowering and maturity were recorded in plants applied with $\mathrm{N}_{100} \mathrm{P}_{60} \mathrm{~K}_{100}$. The results agreed with Heather et al. (2012) who reported that potassium in $\mathrm{N}$ and $\mathrm{K}$ 
combination applied to tomato stimulated early flowering and maturity. In this study, the deficiency of $\mathrm{P}$ in control plants where $\mathrm{N}, \mathrm{P}$ and $\mathrm{K}$ was not applied resulted in late flowering and prolonged maturity. These results were in agreement with Zeri and Obreza (2003) who stated that low levels of N, P and K limit plant growth and development due to their negative effects on photosynthetic and carbohydrate production, which prolong vegetative and reproductive growth stages of tomato hence leading to late flowering and maturity.

Unlike for plant height, the highest cherry tomato yield was obtained in season 2016B and the least in 2017A. This was attributed to variation in rainfall amounts received during the different tomato growth stages. In 2016B moderate rainfall was received during the vegetative stage (September-October) and high rainfall was received during the reproductive stage (November-December), while in season 2017A high rainfall was received during vegetative stage (March-April) and moderate rain during reproductive stage (May-June). In cherry tomato moisture availability associated with high rainfall received during early growth, the stage is known to promote luxurious vegetative growth which shortens reproduction, yet reproductive stage contributes more to the total yield. Therefore, the high rainfall received during the reproductive stage in season 2016B explained the high tomato yield obtained during the same season.

The average tomato yield in the study was increased significantly by application of $\mathrm{N}_{100} \mathrm{P}_{60} \mathrm{~K}_{100}$ which provided $8 \%$ higher yield over the control. The low levels of N, P and $\mathrm{K}$ in control plants negatively affected tomato yield. These results agreed with Imas (1999), and Zeri and Obreza (2003) findings which stated that the low levels of $\mathrm{N}, \mathrm{P}$ and $\mathrm{K}$ results into smaller tomato fruits, because the rate of photosynthetic activity of tomato drops sharply, hence reducing growth and compromising yield. On the other hand, the high levels of N, P and K for plants applied with $\mathrm{N}_{200} \mathrm{P}_{60} \mathrm{~K}_{200}$ also affected tomato yield negatively, indicating that higher levels of fertilizer application don't translate into better yield. Based on the study findings it can be observed that increase in cherry tomato yields is contributed by increasing levels of $\mathrm{N}, \mathrm{P}$ and $\mathrm{K}$ applied. However, this increment cannot go beyond $\mathrm{N}_{100} \mathrm{P}_{60} \mathrm{~K}_{100}$ because above this level decreasing trend in tomato yield begins to be observed.

\section{Conclusion}

This study concluded that increasing levels of $\mathrm{N}$ and $\mathrm{K}$ over the control increases cherry tomato height and yield, and reduces the days to flowering and maturity. In other wards as levels of $\mathrm{N}$ and $\mathrm{K}$ are increased beyond (100 $\left.\mathrm{kg} \mathrm{ha}^{-1}\right)$, reduction in tomato height and yield sets in and tomato flowering and maturity periods are shortened. Based on this study, application of 100,60 and $100 \mathrm{~kg} \mathrm{ha}^{-1}$ of N, P and K should be adopted by cherry tomato farmers to increase their yields in central Uganda where the study was conducted.

\section{Acknowledgements}

The research was funded by NARO Competitive Grant Scheme through a World Bank Grant and Government of Uganda. The authors are grateful to National Crops Resources Research Institute (NaCRRI), for hosting the research and Kyambogo University for providing cherry tomato germplasm used in the study.

\section{References}

Abu-El Samen, F. M., Goussous, S. J., Jendi, A. A., \& Makhadmeh, I. M. (2015). Evaluation of tomato early blight management using reduced application rates and frequencies of fungicide applications. International Journal of Pest Management, 61(4), 320-328. https://doi.org/10.1080/09670874.2015.1059969

Anderson, J. M., \& Ingram, S. J. (1993). Tropical soil biology and fertility: A handbook of methods. CAB International, Wallingford, UK. https://doi.org/10.1097/00010694-199404000-00012

Araujo, J. C., Telhado, S. F. P., Sakai, R. H., Ledo, C. A. S., \& Melo, P. C. T. (2016). Univariate and multivariate procedures for agronomic evaluation of organically grown tomato cultivars. Horticultura Brasileira, 34, 374-380. https://doi.org/10.1590/S0102-05362016003011

Beckles, D. M. (2012). Factors affecting the postharvest soluble solids and sugar content of tomato (Solanum lycopersicum L.) fruit. Postharv. Biol. Technol, 63, 129-140. https://doi.org/10.1016/j.postharvbio.2011. 05.016

Bouyoucos, G. J. (1927). The hydrometer as a method for the mechanical analysis of soils. Soil Sci., 23, 343-353. https://doi.org/10.1097/00010694-192705000-00002

Bremner, J. M., \& Mulvaney, C. S. (1982). Nitrogen-total. In A. L. Page, R. H. Miller, \& D. R. Keeney (Eds.), Methods of Soil Analysis (Pt. 2, 2nd ed., pp. 595-614). Agron. Monogr. 9. ASA, Madison, WI.

Dry, P. R., \&Loveys, B. R. (1998). Factors influencing grapevine vigor and the potential for control with partial rootzone drying. Australian Journal of Grape and Wine Research, 4, 140-148. https://doi.org/10.1111/ j.1755-0238.1998.tb00143.x 
El-Bassiony, A. M. (2006). Effect of Potassium Fertilization on Growth, Yield, and Quality of Onion Plants. J. Appl. Sci. Res, 10, 780-785.

Gupta, C. R., \& Sengar, S. S. (2000). Response of tomato (Lycopersicon esculentum Mill.) to nitrogen and potassium fertilization in acidic soil of Bastar. Vegetable Science, 27, 94-95

Heather, L. M., Hamid, A., \& Majid, R. F. (2012). Selective genotyping to identify late blight resistance genes in an accession of the tomato wild species Solanum pimpinellifolium. Euphytica, 187, 63-75. https://doi.org/ 10.1007/s10681-012-0729-6

Huang, B. (2000). Waterlogging responses and interaction with temperature, salinity, and nutrients. In R. E. Wilkinson (Ed.), Plant Environmental Interaction. New York, NY, USA. https://doi.org/10.1201/ 9780824746568.ch8

Imas, P. (1999). Quality aspects of $K$ nutrition in horticultural crops. Proceedings of the IPI-PRII-KKV Workshop on the Recent Trends in Nutrition Management in Horticultural Crops, February 11-12, 1999, India.

Payne, R. W., Murray, D. A., Harding, S. A., Baird, D. B., \& Soutar, D. M. (2011). GenStat for Windows (14th ed.). VSN International, Hemel.

Marschner, H. (1995). Mineral Nutrition of High Plants (2nd ed.). London: Academic Press.

Shao, G., Wang, M., Liu, N., Yuan, M., Kumar, P., \& She, D. L. (2014). Growth and Comprehensive Quality Index of Tomato under Rain Shelters in Response to Different Irrigation and Drainage Treatments. The Scientific World Journal. https://doi.org/10.1155/2014/457937

Okalebo, J. R., Gathua, K. W., \& Woomer, P. L. (2002). Laboratory methods of soil and plant analysis: A working manual (2nd ed.). TSBF-CIAT and SACRED Africa, Nairobi, Kenya.

Olsen, S. R., \& Sommers, L. E. (1982). Determination of available phosphorus. In A. L. Page, R. H. Miller, \& D. R. Keeney (Eds.), Method of Soil Analysis (Vol. 2). Madison, WI: American Society of Agronomy.

Ortas, I. (2013). Influences of nitrogen and potassium fertilizer rates on pepper and tomato yield and nutrient uptake under field conditions. Academic Journals, 8, 1048-1055.

Savvas, D., Ntatsi, G., \& Passam, H. C. (2008). Plant Nutrition and Physiological Disorders in Greenhouse-Grown Tomato, Pepper, and Eggplant. Eur. J. Plant Sci. Biotechnol., 2, 45-61.

Sinnaduiai, S.(1992). Vegetable cultivation. Accra Asempa publication, Accra, Ghana.

Thomas, G. W. (1982). Exchangeable cations. In A. L. Page, R. H. Miller, \& D. R. Keeney (Eds.), Methods of Soil Analysis (Pt 2., pp. 159-165). Agron Monogr, Madison, WI.

Zeri, M., \& Obreza, A. (2003). Plant nutrients for a citrus tree, soil and water science department. Institute of Food and Agricultural Sciences, University of Florida, USA.

Zhen, D. C., Jie, H. J., \& Kui, C. (1996). Studies on fertilizer application levels of seedling stage of eggplant raised with mixed media, China Vegetables, 4, 16-18.

Walkley, A., \& Black, I. A. (1934). An examination of Degtjareff method for determining soil organic matter, and proposed modification of the chromic acid tritation method. Soil Science, 37, 29-38. https://doi.org/10.1097/ 00010694-193401000-00003

YAP. (2016). YAP Proposal\#91: Expanding my tomato farm. Kampala, Uganda. Retrieved from https://www.blog.gfar.net

\section{Copyrights}

Copyright for this article is retained by the author(s), with first publication rights granted to the journal.

This is an open-access article distributed under the terms and conditions of the Creative Commons Attribution license (http://creativecommons.org/licenses/by/4.0/). 